\title{
Enforcement of Fundamental Rights in Nigeria and the Unsolved Issue of Poverty among the Citizens: An Appraisal
}

\author{
Igwe Onyebuchi Igwe, Matthew Enya Nwocha, Amaramiro A. Steve \\ Faculty of Law, Ebonyi State University, Abakaliki, Nigeria \\ Email: nwochaenyaeni@gmail.com
}

How to cite this paper: Igwe, I. O., Nwocha, M. E., \& Steve, A. A. (2019). Enforcement of Fundamental Rights in Nigeria and the Unsolved Issue of Poverty among the Citizens: An Appraisal. Beijing Law Review, $10,1-9$.

https://doi.org/10.4236/blr.2019.101001

Received: November 21, 2018

Accepted: January 14, 2019

Published: January 17, 2019

Copyright (c) 2019 by author(s) and Scientific Research Publishing Inc. This work is licensed under the Creative Commons Attribution International License (CC BY 4.0).

http://creativecommons.org/licenses/by/4.0/

\begin{abstract}
For long time now, there have been intense debates among scholars and legal practitioners on the value of fundamental rights provisions in Nigerian laws to citizens who are impoverished on one hand by wide margin of classes in Nigeria and on the other hand because of the Nigeria's economy. In search for answer to above debates, this paper sets to carry out a surgical diagnosis on the place of poverty in the enforcement of fundamental rights in Nigeria. The research method is doctrinally and conceptually utilized the provisions of national and international legal instruments, decisions of courts as well as contributions of scholars in books and journals to evaluate and analyze the subject matter. The paper discovered that poverty among most Nigerians has posed anti-clock movement on the enforcement of fundamental rights in $\mathrm{Ni}$ geria. It was based on this that we made our recommendations which include the making of socio-economic rights justiciable in Nigerian courts.
\end{abstract}

\section{Keywords}

Rights, Poverty, Citizen, Justiciable, Legal Aid

\section{Introduction}

Over the years, successive democratic governments in Nigeria have continued to include in their political manifestoes the burning issues of respect for human rights and improve standard of living among Nigerians. Despite regimes of campaign promises, poverty among Nigerians keeps widening while enforcement of fundamental rights appears to be on graphical retrogression. One fundamental issue that needs to straighten is that the provisions of fundamental rights under Nigerian laws which have remained mythical in the face of the ina- 
bility of some Nigerians to command resources at a level which is sufficient to obtain a basket of goods and facilities judged to be minimum necessaries in the contemporary circumstances of the Nigerian economy. In this situation, enforcement of fundamental rights takes to self exile while what is left is how to eke a living to avoid starvation to death in place of investing in costly and prolonged litigation bedeviling Nigerian courts. This paper is set to dig deep into the enforcement of fundamental rights in Nigeria and the unsolved issue of poverty among the citizens. In order to drive home the topic under the discourse, the paper will examine the nature of fundamental rights, meaning of poverty and the place of poverty in the enforcement of fundamental rights in Nigeria among others.

\section{Concept of Fundamental Rights}

Fundamental rights are the basic rights of citizens. In other words, they are fundamental because they are crucial to the attainment of individual's freedom in the society. According to Garner (2004), fundamental right is a right derived from fundamental law, example the constitutional law. ${ }^{1}$ Falana (2010) argues that fundamental rights are generally regarded as those aspects of human rights which have been recognized and entrenched in the Constitution of a country. In Ramsome-Kuti v. Attorney General of the Federation ${ }^{2}$ the Supreme Court observed that a fundamental right is a right which stands above the ordinary laws of the land and which in fact is antecedent to the political society itself. This paper quiet agrees with the Supreme Court of Nigeria that fundamental rights precursor to the political society. Fundamental rights are in born in human beings. The only thing the society does is to ensure to their preservation and political blessings. Even when man was in the state of nature according to some political scientists, these rights have been with man and were at no time alienable. ${ }^{3}$

In order to grant political succor to the fundamental rights provisions of the Constitution of the Federal Republic of Nigeria 1999 (as amended), section 46 (1) of the said Constitution provides that: "Any person, ${ }^{4}$ who alleges that any of the provisions this Chapter has been, is being or likely to be contravened in any State in relation to him may apply to a High Court in that State for redress." In the same vein, article 8 of the Universal Declaration of Human Rights provides that: "Everyone has the right to an effective remedy by the competent national tribunals for acts violating the fundamental rights granted him by the constitution or by law." Paragraph 3(c) of the said Rules provides that: "For the purpose of advancing but never for the purpose of restricting the applicant's rights and freedoms, the court may make consequential orders as may be just and expe${ }^{1}$ B.A Garner, Black's Law Dictionary, op cit, p. 744. ${ }^{2}$ [1985] 5 NWLR (Pt. 10) 211 at 229-230.

${ }^{3}$ The Hobbesian and Lockian schools of thought. ${ }^{4}$ In Nemi v. AG Lagos [1996] 6 N.W.L.R. (Pt 452) pp. 42-59, the court held that prisoners are entitled to enforce their rights because of the word, "any person" used by section 46(1) of the Constitution of the Federal Republic of Nigeria 1999 (as amended). 
dients. ${ }^{\circ 5}$ In the same vein, the courts are enjoined to proactively pursue enhanced access to justice for all classes of litigants, especially the poor, the illiterate, the uninformed, the vulnerable, the incarcerated and the unrepresented. ${ }^{6}$ In Idris v. Agumga ${ }^{7}$, the Court of Appeal Abuja Division held that access to court implies approach or means of approach to court without constraint. One of the constraints to access to court in fundamental right cases under discourse is poverty.

\section{Nature of Rights and Origin of Fundamental Rights in Nigeria}

Prior to delving into the nature of fundamental rights, it would be apposite to do conceptual underpin of the nature of right. Garner (2004) explains the nature of right to mean that which is proper under the law, morality, or ethics. It is something that is due to a person by just claim, legal guarantee, or moral principle (Rutherford, 1993). Curzon (1998) argues that right is "that to which a person has just claim." It is an interest which will be recognized and protected by a rule of law, respect for which is a legal duty, violation of which is a legal wrong (Cranston 1962). Okpara (2005) submitted that the expression "right" is derived from the Latin word rectus which means, correct, straight, and not crooked. It is that to which a person has a just and valid claim, whether it be land, a thing or the privilege of doing something or saying something (Ogbu, 2013). Oputa (1989) expanded the concept of right to the end that for him a right in its most general sense is either the liberty (protected by law) of acting or abstaining from acting in a certain manner, or the power (enforced by law) of compelling a specific person to do or abstain from doing a particular thing. In Afolayan v Ogunride \& $\mathrm{Ors}^{8}$ the court held that a right is an interest recognised and protected by the law. In Uwaifo v $A$ G Bendel State the Supreme Court of Nigeria held that a legal right is any advantage or benefit conferred upon a person by a rule of law. For the purpose of this paper, right under discourse is as it pertains to human being otherwise known as human rights. Human rights are inherent in man by virtue of his birth. It represents demands or claims which individuals or group make on society or fellow individuals, some of which are protected by rule of law while others remain aspirations to be achieved later.

In Nigeria, the emergence of fundamental rights became obvious to protect the rights and liberties of the people against tyranny. Available evidence unearthed the fact that as Nigeria was warming up get to gain self-rule, the issue

${ }^{5}$ The Fundamental Rights (Enforcement Procedure) Rules, 2009, Order XI provides that at the hearing of the application under the rules, the court may make such orders, issue such writs and give such directions as it may consider just or appropriate for the purpose of enforcing or securing the enforcement of any of the Fundamental Rights provided for in the Constitution or African Charter (Ratification and Enforcement) Act.

${ }^{6}$ The Fundamental Rights (Enforcement Procedure) Rules, 2009, Preamble 3(d).

${ }^{7}$ [2015] 13 NWLR (Pt.1417) 441 at 463.

${ }^{8}$ [1990] 1 NWLR (pt 127) 369 at 391.

${ }^{9}[1982] 7$ S C 124 at 127. 
that agitated the mind of the minorities was how to preserve the libertarian heritage in the face of ethnic rivalry and ambition to get all which has been the pronounced features of Nigerian politics (Eze, 1984). ${ }^{10}$ This panic situation prompted the minority class within the Autonomous Rights to agitate for their own states. As a result, the then Colonial Secretary constituted a commission headed by Sir Henry Willink to look into the fears of the minorities and suggest ways of allaying the fears (Ogbu, 1999). The Willink Commission reviewed the situation of minorities in Nigeria and rejected the suggestion for the creation of more regions rather recommended for the inclusion of human rights in the successive Nigerian constitutions. The recommendation of Willink Commission was accepted at the 1958 Constitutional Conference and subsequently, became the Chapter III of both the Independence Constitution of 1960 and the Republican Constitution of 1963 (Igwe, 2011). At present, civil and political rights are fundamental under the Constitution of the Federal Republic of Nigeria 1999 (as amended). They are listed under the Chapter four of the Constitution. ${ }^{11}$ While the economic, social and cultural rights are listed in Chapter II of the Constitution of the Federal Republic of Nigeria 1999 (as amended) as Fundamental Objectives and Directive Principles of State Policy. ${ }^{12}$

\section{Meaning of Poverty and Human Rights}

Black's Law Dictionary defines poverty is "The condition of being indigent; the scarcity of the means of sustenance." It is also argued that poverty is "a state of household command over resources at a level which is insufficient to obtain a basket of goods and facilities judged to be minimum necessaries in the contemporary circumstances of the society under study (Aduba, 1991)." People are poor when their incomes are in inadequate for survival. Dressler and Wills examined poverty in two ways: absolute poverty, which is a situation in which, an individual or household, is unable to provide even the basic necessaries of life; and relative poverty, which is a situation in which individual or household is unable to maintain the standard of living considered normal in the society in question. According to McConnel (1969), a family lives in poverty when its basic needs exceed its available means of satisfying them. This is the case in Nigeria. In Nigeria, average civil servants, traders and farmers are living in situations where it is difficult to meet up with minimum standard of living required of a civilised society. The basic necessaries of life appear to be luxuries rather than minimum requirements of life. Poverty represents denial of basic socio-economic needs of individual or group in a society.

\footnotetext{
${ }^{10}$ The global origin of fundamental rights could be traced to the English Magna Carta Act of 1215 and the Bill of Rights of 1689.

${ }^{11}$ The fundamental rights under the Constitution include; right to life; dignity of human person; liberty, fair hearing; private and family life; freedom of thought, conscience and religion; freedom of expression and press; peaceful assembly and association; movement; freedom from discrimination; right to acquire and own immoveable property among others.

${ }^{12}$ These include right to clothing, feeding, housing, education, healthcare among others. These rights are not justiceable under the Constitution of the Federal Republic of Nigeria 1999 (as amended).
} 
Oputa (1989) described poverty as "another modern form of slavery."13 According to Awolowo (1981), poverty is a condition which exists when a person lacks the means of satisfying the necessaries of life. He contended that the characteristics of poverty are well known and they include under-nourishment or malnutrition, wretched and degrading shelter, shabby clothing, total lack of any kind of comfort and luxury. He further stated that because of his malnutrition and his physical and psychological degrading conditions of living, he is inefficient, his productivity is hopelessly low, he is technically ignorant, he succumbs readily to disease, he has little zest for life, he has little or no enthusiasm for what he does and in consequence of all these, his poverty persists on an increasing scale. The United Nations Committee on Economic, Social and Cultural Rights describes poverty as "a human condition characterized by sustained or chronic deprivation of the resources, capacities, choices, security and power necessary for the enjoyment of an adequate standard of living." ${ }^{14}$ No man is created to be poor but poverty can be bred from the circumstances of birth and the condition of living created by the society one finds himself. In a country where it is difficult to provide adequate food, housing, medical care and social security, the battle face by the citizens is how to provide the basic needs of the family rather chasing the white goose of enforcement of rights. Poverty driven society is characterized by slums and shanty houses, poor road network, low productivity, poor mental development and credulity to any peanut that comes their way from the class of the affluent. Poverty breeds poverty. People who are poor have limited access to healthcare, education and information. The result of poor education is endless circle of poverty and denial of necessaries of life. The mention of poverty sounds illusory to the affluent but the truth is that one needs to take a practical course in poverty before would appreciate the meaning.

\section{The Place of Poverty in the Enforcement of Fundamental Rights in Nigeria}

Poverty is one of the impediments to the realisation of the enforcement of fundamental rights in Nigeria (Ezejiofor 1964). Although it is commonly said that court is the last hope of the common man, in practice going to court has some financial implications. The litigant has to pay filing fees, he has to engage the services of a lawyer and pay his bills among others. This makes the mission impossible to many Nigerians especially the poor and the incarcerated. According to Oputa (1989), in search for justice and redress resulting in the effectuation of his rights, the ordinary citizen of Nigeria is caught in the mess of a rather vicious circle where the court cannot adjudicate upon and effectuate his rights unless there is a suit complaining about the breach or threatened breach of these rights filed in court; and where there is an awareness of the right and the knowledge or

\footnotetext{
${ }^{13} \mathrm{CA}$ Oputa, "Human Rights in the Political and Legal Culture of Nigeria", $2^{\text {nd }}$ Idigbe Memorial Lectures (Lagos: Nigerian Law Publications Ltd, 1989) p. 94.

${ }^{14}$ General Comment 8, Substantive Issues Arising in the Implementation of the International Covenant on Economic, Social and Cultural Rights, UN Doc E/C 12/2001/10, para 12.
} 
realisation of its breach or threatened breach and the courage to prosecute the claim, the luxury of a costly and prolonged litigation up to the Supreme Court could be a challenge.

What disturbs our mind is that the Constitution of the Federal Republic of Nigeria, 1999 (as amended) provides in its preamble that the Constitution is for the purpose of, "promoting the good government and the welfare of all persons ${ }^{15}$ in our country on the principles of Freedom, Equality and Justice." How do we promote the welfare of all persons including the poor in Nigeria on the principles of 'Freedom, Equality and Justice' when the poor cannot access the court because of the high cost of litigation coupled with delays in determination of cases occasioned by our laws? How can we promote the welfare of all persons including the poor in Nigeria on the principles of 'Freedom, Equality and Justice' where the ability to put bribe in the right hand of security agencies makes the difference between freedom and incarceration? In practice, only the rich, the powerful and the dominant class seem to have all the rights in Nigeria while the poor, the weak, the down-trodden and the incarcerated are left to suffer in silence, to be patient, kneel down and ask God to intervene in their circumstances. How can a poor person gather evidence to commence application for enforcement of his right? Where does he get money to pay for his claim? What about lawyer's fees? In the above situations, the poor is left to wonder in his hopelessness. From the above, it is clear that the institutional framework through which the poor in Nigeria can realize their rights is working against them.

It is on record that section 33 of the Constitution of the Federal Republic of Nigeria 1999 (as amended) provides for a right to life. This right is fundamental, sacrosanct and inalienable. However, right to life cannot be fully realized in the absence of life supporting necessaries like food, shelter and clothes. In a country like Nigeria where many people are living below starvation, the provision of right to life is a tale by the moonlight. Falana argues that Nigerians "ought to realize that without food, the right to life is meaningless to marginalized and vulnerable segment of the population (Falana, 2010). Aguda (1985) laments that the right to life has little meaning without the basic necessaries that sustain it. The protection of right to life means nothing to poor Nigerians who are hound upon and killed extra judicially by security agencies that are paid to protect them. It means nothing to a man who cannot be protected by the attack of herdsmen and other bloodletting sects. It means nothing to a man who cannot access medical facilities of the country because of the cost implication. It means nothing to a man who cannot raise money to file claim in the court to ventilate infraction of his right to life.

The right to dignity of human person provided under section 34 of the Constitution of the Federal Republic of Nigeria 1999 (as amended) cumulates to right not be subject to inhuman, degrading punishment or torture. How can this right be realized in a country where there are class distributions of wealth? The

${ }^{15}$ All persons in the context of the Constitution include the poor and the downtrodden. 
right to dignity of human person cannot strive in a country where the poor are coerce to make extrajudicial statement in police station because they cannot bribe the investigating police officer. Right to dignity means nothing to people that stay awake during some nights because of drops of water falling on them due to leakages in their thatched houses. Does a right to dignity means anything to man who is living in a house that qualifies to house poultry or piggery and a man who cannot afford a pair of shoe? A wretched man can easily succumb to every odd job to enable him get paid by the rich in order to put food on his table. Even after he had done the job and the rich fails to pay him, he may not complain because he needs the job again to enable him feed.

Right to liberty ${ }^{16}$ entails that one is free from restrictions except if it is done in accordance with the rule of law. This means nothing to a man who is by nature imprisoned by poverty. It means nothing to a man who cannot afford a service of a lawyer if his liberty is unjustly restricted by the law enforcement agents. In this situation, the poor is left at the mercy of the law enforcement agents to determine between their liberty and incarceration. The right to fair hearing enshrined in the Constitution ${ }^{17}$ means nothing to man who cannot pay for filing of court summons. Majority of Nigerians who are living in rural areas are living in conditions of abject poverty for which their struggle is between want and provision of basic needs. Fair hearing cannot strive in country where wealth is unequally distributed. A poor has no business in pursuing his right to fair hearing in a situation where he may risk his family survival due to hunger in the name of pursuing costly and endless battle in courts in order to get his right to fair hearing ventilated (Aguda, 1985). The question is does fair hearing mean anything to a poor person who cannot pay for court summons let alone afford the services of a legal practitioner? It is beyond argument that poverty is a stigma in Nigeria. It makes a man to lose strength of how to coordinate himself, his appearance and his thinking let alone fighting for his right.

Right to private life cannot strive in Nigeria where majority of citizens cannot afford decent houses and some many are displaced from their homes as a result of urban renewal projects from governments or due to crisis as a result of the inability of the governments provide needed security. Freedom expression ${ }^{18}$ is worthless to a man who is engulfed in every day battle on how to defeat hunger and safe his family from starvation. How can expression be free in a society where so many people have lost their jobs, risked assassinations and branded opponents because they aired their views in governments' programmes? Freedom of expression cannot flourish in country where poverty has injected fears in many people from speaking against the wealthy class. In a society where the right to education is an illusory, the right to freedom of expression is not relevance to millions people who do not know how to access information correctly and ask relevant questions concerning how governments spend the collective

\footnotetext{
${ }^{16}$ Section 35 of the Constitution of the Federal Republic of Nigeria 1999 (as amended).

${ }^{17}$ Section 36 of the Constitution of the Federal Republic of Nigeria 1999 (as amended).

${ }^{18}$ Section 37 of the Constitution of the Federal Republic of Nigeria 1999 (as amended).
} 
common resources of the nation. There is no how the right to freedom of thought, conscience and religion ${ }^{19}$ will strive in a country that is engulfed with religion crisis which metamorphose to burning of worship centers and sharing of the national cakes along the religious divide. In the same vein, the right to acquire immoveable property anywhere in Nigeria is an imaginary in a country where people are afraid of living in some part of the country because of discrimination across religion divide. In the consequence, the actualization of fundamental rights enshrined in the Constitution of the Federal Republic of Nigeria 1999 (as amended) cannot be successfully prosecuted in the midst of the unsolved issue of poverty among the citizens of Nigeria. Bhagwati remarks that the only solution for making fundamental rights meaningful to everybody is to make conditions of living meaningful through the recognition of socio-economic justice for all. ${ }^{20}$

\section{Recommendations}

It is germane to acknowledge that fundamental rights cannot be fully realized in a country where the socio-economic rights are dreams for later interpretations. Aguda (1985) argued that if a Bill of right is to make sense, it must include among others, a right to work and to a living wage, a right to shelter, to health, to education. And that is the least we can strive for if we are ever going to have a society which realizes basic human rights. On the strength of the above, the paper strongly recommends that socio-economic rights in Nigeria be made justifiable so that enforcement of fundamental rights will be real rather rhetoric. Chapter III of the Nigerian Constitution which provides for socio-economic rights cannot be enforced in any court because Section 6(c) of the Constitution forbids any court from entertaining questions emanating from the said chapter. This is anomalous and should be reversed by amendment of the Constitution. It is also important that probono legal service in human rights cases be made part of the mandatory requirements for lawyers to access their stamp and seal annual for the purpose of legal practice. Providing free services by lawyers to indigent litigants is one of the ways to help poor people enforce their rights. The cost of filing court process in cases bordering on breach of human rights should be made minimal so as to be accessible to everybody. The high cost of filing human rights applications is the major reason why poor people find it difficult to enforce their rights and this should be remedied by way of reduction of cost of litigation. Awareness is very important tool that should be introduced by NGOs and everybody on campaigns on the enforcement of fundamental rights. Social consciousness and awareness should be created to enhance the observance of human rights in the country.

\section{Conclusion}

What emerged from the discussion of this paper is that the unresolved issue of

${ }^{17}$ Section 38 ibid.

${ }^{20} \mathrm{Bhagwati}$ is the former Chief Justice of India. 
poverty in Nigeria has remained a barrier to enforcement of human rights in Nigeria. The priority of poor Nigerians is not to invest in prolonged and costly litigation rather how to ensure that they save themselves and their families from starvation. Until the rights to basic necessaries of life are made justiceable in $\mathrm{Ni}$ geria, the enforcement of fundamental rights under the Nigerian constitution will continue to remain a mirage.

\section{Conflicts of Interest}

The authors declare no conflicts of interest regarding the publication of this paper.

\section{References}

Aduba, J. N. (1991). Impact of Poverty on the Realisation of Fundamental Human Rights. Journal of Human Rights Law and Practices, 3, 3.

Aguda, T. A. (1985). A New Perspective in Law and Justice in Nigeria. Distinguished.

Awolowo, O. (1981). Path to Nigerian Greatness. Enugu: Fourth Dimension Publishers Co. Ltd.

Cranston, M. (1962). Human Rights Today. New York: Basic Books.

Curzon, L. B. (1998). Dictionary of Law (5 ${ }^{\text {th }}$ Edition). Great Britain: Redwood Books.

Eze, O. C. (1984). Human Rights in Africa. Nigeria: MacMillan.

Ezejiofor, G. (1964). Protection of Human Rights under the Law. London: Butterworths.

Falana, F. (2010). Fundamental Rights Enforcement in Nigeria ( $2^{\text {nd }}$ Edition). Lagos: Legal Text Publishing Company Ltd.

Garner, B. A. (2004). Black's Law Dictionary (8 ${ }^{\text {th }}$ Edition). USA: Thomson West Publishing Co.

Igwe, I. O. (2011). An Appraisal of the Provision of Order XIII of the Fundamental Rights (Enforcement Procedure) Rules 2009. EBSU LJ.

McConnel, C. R. (1969). Economics: Principles, Problems and Policies (4 $4^{\text {th }}$ Edition). New York: McGraw Hill Inc.

Ogbu, O. N. (1999). Human Rights Law and Practice in Nigeria: An Introduction. Enugu: CIDJAP Press.

Ogbu, O. N. (2013). Human Rights Law and Practice in Nigeria (Vol. 1, $2^{\text {nd }}$ Revised Edition). Enugu: Snapp Press Nigeria Ltd.

Okpara, O. (2005). Human Rights Law \& Practice in Nigeria (Vol.1). Enugu: Chenglo.

Oputa, C. A. (1989). Human Rights in the Political and Legal Culture of Nigeria. In $2^{\text {nd }}$ Idigbe Memorial Lectures, Lagos: Nigerian Law Publications Ltd.

Rutherford, L., et al. (1993). Osborn's Concise Dictionary ( ${ }^{\text {th }}$ edtion). London: Sweet \& Maxwell. 